\title{
CELESTINESCA
}

\author{
https://doi.org/10.7203/Celestinesca.10.19628
}

\section{A POSSIBLE hIDDEN ALLUSION IN 'CELESTINA'}

\author{
Ted E. McVay, Jr. \\ Louisiana State University
}

\begin{abstract}
In octaves added to the Toledo 1500 Comedia, Alonso de Proaza, possibly acting in collusion with Fernando de Rojas, 1 first revealed the acrostic key to its authorship hidden in Rojas' preliminary verses. In the Zaragoza 1507 Tragicomedia are added the three octaves entitled "Concluye el auctor aplicando la obra al propósito por que la acabó." There is obviously no acrostic formed by the first letters of each line of these latter verses: PaAaLvpdNnqpDcceYmza Ptds. In the column formed by the eighth letter in each line, the letters are: is Acocoenodertssmseescbm. The latter half of these letters seems to make no sense whatever as is the case with the case with the first column and the rest of the columns. However, when written Isaco Coeno de, the first half closely resembles the proper name, Isaac Cohen.
\end{abstract}

While this arrangement and reading could be coincidental, a study of the preliminary acrostic verses, of the three octaves at the end of Celestina, and of Proaza's addenda, yields mainly. words of three, four and five letters, with the following longer resemblances, some of which are also interesting: uno se yama (col. 3, lines 26$34)$, deo gesus $(7,6-13)$, and loen deo $(15,37-43$, along with two other instances of deol in the preliminary verses; el xuez $(12,12-17)$ in the "Concluye..."; and detonar (22, 23-29 in Proaza's verses. An examination of the eighth column of the final stanza or the acrostic verses of the Toledo 1500 Comedia, much of which was reworked into the first stanza of the "Concluye...."3 shows a correspondence of only four letters of the eight (oeactche).

Consideration of the possibility that the likeness may not be ascribed to coincidence calls for an examination of the surname Cohen (from Hebrew, kohen, "priest"). The name was, of course, common in spain until 1492. Pilar León Tello in Judíos de Toledo lists Cohens from Alcalá, Cuenca, Guadalajara, Santa Olalla, Talavera and Toledo.4 The name was so easily recognizable that Rodrigo de cota used it along with other common Jewish surnames in his "Epitalamio," a diatribe against a New Christian relative of his who 


\section{CELESTINESCA}

neglected to invite him to a wedding. He speaks of the lineage of the groom:

De vn aguelo avenzuzen

y del otro Abenamias:

de la madre Sophomias

del padre todo Cohen. 5

As for the rendering Coeno of the name cohen, the omission of the $\underline{h}$ may be explained by Menéndez Pidal. 6 He refers to the advanced state of the loss of the pronunciation of the $h$ in part of Salamanca by 1500 . The variants of the name Yehudá recorded by León Tello include Yudá (2: 573), Hudá (2: 602) and Udá (2: 557).

The addition of the final o presents another problem. Although in Leon Tello there occur examples of the addition of vowels to the end of the name--coheny. $(2: 160)$ and Coheneso (1: 71)--the form ' $\mathrm{Co}(\mathrm{h})$ eno' does not appear. The word 'cohino,' an adjective derived from 'cohen' appears in the Cancionero de Baena. ${ }^{7}$

The problem of the final o also occurs with 'Isaco.' Isaac was a very popular Jewish name judging from the number of times it is cited by León Tel10. Its variants there number at least twenty-one and range from Abishac to Zag. The addition of a final vowel occurs with the form 'Ysaqui' and with the most common form, 'Isaque/Ysaque.'

The bearers of the name Isaac Cohen in Spain include the illustrious Talmudic scholar, Isaac ben Jacob Hakohen Alfasi (1013-1103), teacher of the poets Judah Halevi and Moses ibn Ezra, 8 and Isaac ben Jacob Hacohen of Soria, a cabalist writer who flourished in the mid-13th century. 9

León Tello includes several references to Isaac Cohens who were contemporaries of Rojas as well as residents of areas near those inhabited by him. There was Rabi Cag Cohen of Alcalá, son of Mosé Cohen, mentioned in a 1464 document (2: 325) and a Rabi Ça Cohen, son of don Jacob, who in 1469 owed money for "los préstamos de Segovia" (2: 388). There was also a Rabi Ça Cohen "el Viejo" who had houses in Huete in $1492(1: 544)$. Isaque Cohen "el Bermejo" was the arrendador of tithes for the church of San Julian in Santa Olalla in 1475. (1: 248). In Talavera there lived an Ysaque Cohen, an albardero who was deceased by 1477 (2:444).

There is another allusion to an Ysaque Cohen. Juan de Sevilla, a converso from Toledo, was denounced to the Inquisition in 1486 as judaizante for having gone to Puebla de Montalbán to observe the Passover. Gilman quotes the testimony: "While there, 'he called himself don Ysaque, and he consorted with Jews, and walked with them, and he ate in their houses during the whole of Passover, and he went to 


\section{CELESTINESCA}

the synagogue." 10 In nis defense, Juan de sevilla listed his enemies and included one "don Ysaque Cohen que llaman Angel, tyntorero" (León Tello, 1: 273).

In 1492, the houses of an Isaque Cohen in Toledo became the property of the wife of a Dr. Cota (León Tello, 1: 286). León Tello indexes a 1496 document $(2: 601)$ which refers to the same property under the name Rodrigo de Cota, who was none other than the reputed author of Celestina's first act. However, according to Scholberg, Dr. Cota was Rodrigo's brother, Dr. Alonso Cota, who had been burned in an auto da fé in 1486 . il

The Iast mentioned Isaac Cohen is very tempting to the imagination of the readers and scholars of Celestina. Speculation as to what relation might have existed between Rojas or Celestina and this or some other Isaac Cohen can run the gamut of the unanswered questions which surround the work, from possible collaborator in writing the five acts included in the Tragicomedia, 12 to the "amigo" to whom the prefatory letter is addressed, to the author of the first act. It could be the secret name of a judaizante or merely the former (or traditional) name of a converso, and the range of possibilities for such a reference could extend to Rojas himself. It might even be an inside joke, albeit a dangerous one, known to but a few close friends.

Of course these possibilities are merely possibilities and will remain so until the question of the existence of "Isaco Coeno" is resolved. Only further evidence will bring speculation into the realm of the meaningful and clarify whether these ten letters form an aliusion or an illusion.

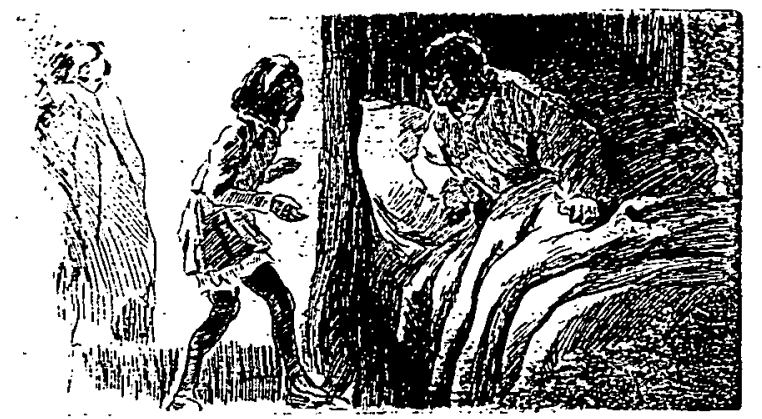

Acto XIII ${ }^{\circ}$. Calis to se entera de la muerte de Sempronio y Pármeno. Ilustración por J. Segrelles. valencia, 1946. 
NOTES

${ }^{1}$ S. Gilman, The Spain of Fernando de Rojas (Princeton: Princeton Univ. Press, 1972), 54 .

$2_{F}$. de Rojas, La Celestina, ed. M. Criado de Val y G. D. Trotter (Barcelona: Bruguera [1Ith ed.], 1981), 321 . References will be to this edition.

${ }^{3} \mathrm{D}$. W. MCPheeters, El humanista español Alonso de Proaza (Valencia: Castalia, 1961), 182 .

${ }^{4}$ Pilar León Tello, Judios de Toledo, 2 vols. (Madrid: CSIC, 1979. All subsequent references to Leon Tello will appear in the text, noting vol. and page numbers.

$5_{K}$. R. Scholberg, Sátira e invectiva en la España medieval (Madrid: Gredos, 1971), 321 .

6 Menéndez Pidal, orígenes del español, 3 rd ed. (Madrid: Espasa-Calpe, 1950), 231 .

${ }^{7}$ Scholberg, 307 .

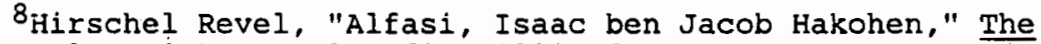
Universal Jewish Encyclopedia, 1939 ed.

${ }^{9}$ Gershom G. Scholem, Major Trends in Jewish Mysticism (New York: Schocken, 1954), 120, 178 .

$10 \mathrm{Gilman}, 238-39$.

$11_{\text {Scholberg, } 323,326 .}$

$12 \mathrm{M}$. R. Lida de Malkiel, La originalidad artistica de 'La Celestina' (Buenos Aires: EUDEBA, 1962), 24.

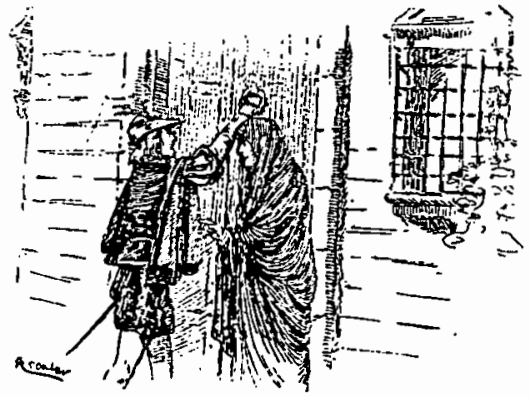

Acto $\mathrm{I}^{\circ}$. Ilustración por Escobar. LC, Barcelona, 1888. 